\title{
The effect of alendronate on the expression of important cell factors in osteoclasts
}

\author{
QINGHONG ZHANG ${ }^{1}$, MENGTAO LIU ${ }^{2}$, YI ZHOU ${ }^{1}$, WEI LIU ${ }^{1}$, JUXIANG SHEN ${ }^{1}$, YANQING SHEN ${ }^{1}$ and LI LIU ${ }^{1}$ \\ ${ }^{1}$ Department of Prosthodontics, Stomatology Hospital, College of Medical Sciences, Zhejiang University, Hangzhou, \\ Zhejiang 310006; ${ }^{2}$ Department of Prosthodontics, Hengha Stomatology Hospital, Hangzhou, Zhejiang 310013, P.R. China
}

Received March 27, 2013; Accepted June 24, 2013

DOI: $10.3892 / \mathrm{mmr} .2013 .1630$

\begin{abstract}
This study investigated the effects of alendronate (ALN) on critical cell factors in osteoclasts. RAW 264.7 cells were induced by sRANKL to change to mature osteoclasts. On the sixth day of incubation, the osteoclasts were treated with ALN at various concentrations and for different incubation times. The concentration groups included $10^{-5} \mathrm{M}, 10^{-6} \mathrm{M}$ and $10^{-7} \mathrm{M}$ ALN, respectively. The cells were incubated for 0 (control group), 2, 4, 6 and $8 \mathrm{~h}$ for each dose group. The mRNA and protein expression of tartrate-resistant acid phosphatase, carbonic anhydrase II, osteoclast-associated receptor and FAS/FASL genes in osteoclasts was analyzed. A concentration- and time-dependent decrease in the mRNA and protein expression levels of the five genes was observed, and no significant difference between the two control groups was observed $(\mathrm{P}>0.05)$. Notably, significant differences between any two experimental groups were observed $(\mathrm{P}<0.05)$. Thus, ALN significantly decreased the expression of critical factors involved in osteoclast function.
\end{abstract}

\section{Introduction}

Osteoclasts are involved in bone resorption by releasing important cell factors (1-3). Several important proteins are involved in bone remodeling, including tartrate-resistant acid phosphatase (TRAP), which is also a specific marker of osteoclasts. Immunohistochemical staining of TRAP is

Correspondence to: Dr Mengtao Liu, Department of Prosthodontics, Hengha Stomatology Hospital, 20 Gu-dun Road, Hangzhou, Zhejiang 310013, P.R. China

E-mail: cellresearch@163.com

Abbreviations: ALN, alendronate; TRAP, tartrate-tesistant acid phosphatase; OSCAR, osteoclast-associated receptor; CAII, carbonic anhydrase II; sRANKL, soluble recombinant murine soluble receptor activator of $\mathrm{NF}-\kappa \mathrm{B}$ ligand

Key words: osteoclasts, alendronate, tartrate-resistant acid phosphatase, carbonic anhydrase II, osteoclast-associated receptor, FAS, FASL one of the most commonly used methods for distinguishing osteoclasts from other cell types $(4,5)$. In addition, carbonic anhydrase II (CAII) is involved in the acid demineralization of osteoclasts $(6,7)$. CAII is a metal enzyme that possesses one active site containing $\mathrm{Zn}^{2+}$ and catalyzes the $\mathrm{CO}_{2}+\mathrm{H}_{2} \mathrm{O} \leftrightarrow \mathrm{HCO}_{3}^{-}+\mathrm{H}^{+}$reaction. CAII synthesizes $\mathrm{H}_{2} \mathrm{CO}_{3}$ by combining $\mathrm{CO}_{2}$ with $\mathrm{H}_{2} \mathrm{O}$ against the concentration gradient, which provides an abundance of $\mathrm{H}^{+}$for the acid demineralization of bone tissue. When CAII function is inhibited at the protein level or via gene mutation, osteosclerosis may occur. Previous studies demonstrated that the osteoclast-associated receptor (OSCAR) is involved in a series of osteoclast activities including differentiation, maturation and recruitment (8-11). Moreover, OSCAR is overexpressed during the acute stage of arthritis; however, not during the resting stage. The inhibition of the OSCAR function also results in a reduction of bone loss. As osteoclasts are a type of terminally differentiated cell, apoptotic mechanisms are critically important in the regulation of the cell. The FAS/FASL is an important pathway in apoptosis and is critical in osteoclast apoptosis (12-14). The functional expression of TRAP, CAII, OSCAR and FAS/FASL in osteoclasts is an important focus of current research, and several studies have investigated potential inhibitors of these factors as a way of preventing or delaying bone loss.

Alendronate (ALN; 4-amino-hydroxybutylidene-bisphosphonate) is a third generation bisphosphonate that has been shown to be a potent osteoclast inhibitor and treatment with ALN results in a reduction of bone loss (15-20). ALN inhibits bone loss by decreasing bone turn-over, increasing bone mass and reducing the number of bone fractures without leading to any type of mineralization disorder. However, osteoclasts are differentiated cells that cannot be passaged, and therefore it is difficult to assess the functions and responses of various cell factors on these cells. Thus, the effects of ALN on TRAP, CAII, OSCAR and FAS/FASL gene expression in osteoclasts remain to be elucidated.

Previously we hypothesized that ALN may exhibit an effect on critical factors involved in osteoclast function based on the correlation between stress stimuli and osteoclast response $(4,7)$. In the present study, the mRNA and protein expression of TRAP, CAII, OSCAR and FAS/FASL were analyzed in osteoclasts following the treatment of cells with ALN at various concentrations and incubation times. 


\section{Materials and methods}

In vitro culture of RAW264.7 cells. RAW264.7 cells (ATCC TIB-71, Chinese Academy of Medical Sciences, Beijing, China) isolated from the murine mononuclear/macrophagic system were cultured in Dulbecco's modified Eagle's medium (high glucose, no. 21013024, Gibco BRL, Carlsbad, CA, USA). When the cells reached $80 \%$ confluence, the adherent cells were scraped away, using a cell scraper, from the $25 \mathrm{~cm}^{2}$ cell culture flask surface (no. 353108, BD Biosciences, Franklin Lakes, NJ, USA) and a uniform cell suspension was prepared for osteoclast culture.

In vitro osteoclast culture. The RAW264.7 cell suspension was seeded in 6-well plates at a density of $1 \times 10^{4}$ cells/well. The osteoclast induction culture medium contained $80 \mu \mathrm{g} / \mathrm{ml}$ soluble recombinant murine soluble receptor activator of NF-K $\beta$ ligand (sRANKL; no. 315-11, Peprotech, Inc., Rocky Hill, NJ, USA), $10 \%$ fetal bovine serum (no. 16000-044, Gibco BRL), $100 \mathrm{U} / \mathrm{ml}$ penicillin, $100 \mu \mathrm{g} / \mathrm{ml}$ streptomycin and $2 \mathrm{mmol} / \mathrm{l}$ glutamine. The medium was changed every three days. On the sixth day of culture, mature osteoclasts were observed and photographed under an inverted microscope and photo system (no. IX51-A21PH, Olympus Corp., Tokyo, Japan).

TRAP staining for osteoclast identification. On the sixth day of culture, mature osteoclasts were harvested and stained for TRAP according to the manufacturer's instructions of the TRAP staining kit (no. 387A, Sigma-Aldrich, St. Louis, MO, USA). An inverted microscope and photo system were used to observe the stained mature osteoclasts.

Experimental groups. The induced mature osteoclasts were incubated with $0 \mathrm{M}$ (control group), $10^{-7} \mathrm{M}$ (low concentration), $10^{-6} \mathrm{M}$ (medium concentration) and $10^{-5} \mathrm{M}$ (high concentration) ALN (no. 126855-100MG, Molar Mass 325.1, Merck KGaA, Darmstadt, Germany) for 2, 4, 6 and $8 \mathrm{~h}$. The mRNA and protein expression of TRAP, CAII, OSCAR and FAS/FASL were then detected by qPCR and western blot analysis for each time point.

$q P C R$. Primers for the five genes were designed using Primer Premier 5.0 software (Premier Biosoft, Palo Alto, CA, USA) and then synthesized in the laboratory. The primer sequences for the five genes and annealing temperatures are listed in Table I. The reagents included Fermentas RevertAid ${ }^{\mathrm{TM}}$ First-Strand cDNA Synthesis kit (no. K1622, MBI Fermentas Corp., Hanover, NH, USA), RNA extraction kit (TRIzol, no. 15596018 , Invitrogen Life Sciences, Carlsbad, CA, USA), Taq DNA polymerase (no. B1263, Promega Corp., Beijing, China), gel imaging analytical system (no. 2200, Alpha Corp., USA), GeneAmp PCR system (no. 9700, Applied Biosystems, Foster City, CA, USA) and ultraviolet spectrophotometer (no. DU800, Beckman Coulter Inc., Miami, FL, USA). Routine PCR consisted of RNA extraction, first-strand cDNA synthesis, PCR amplification of the target gene fragment, gel electrophoresis and imaging. The integrated optical density of the electrophoresis strips for the five genes was recorded for analysis and DNase treatment of the samples was performed. In addition, the amplification was confirmed to be in the linear phase when the measurements were taken. The PCR reaction conditions were as follows: Initial denaturation at $95^{\circ} \mathrm{C}$ for $2 \mathrm{~min}, 32$ cycles of denaturation at $95^{\circ} \mathrm{C}$ for $30 \mathrm{sec}$, renaturation for $30 \mathrm{sec}$ and extension at $72^{\circ} \mathrm{C}$ for $30 \mathrm{sec}$.

Western blot analysis. The predominant reagents used were as follows: 10X Ponceau S (no. P0370, BioHao Corp., China), Tris-Glycine buffer (no. 28380, Thermo Fisher Scientific, Waltham, MA, USA), Tris-buffered saline (TBS) solution (no. 0788-2PK, Amresco Inc., Solon, Ohio, USA), confining liquid (No. PA106-01, Tiangen Corp., Beijing, China), 10X TBS with Tween-20 (TBST) solution (GMS12130, Genmed Corp., Zoetemeer, The Netherlands), polyvinylidene fluoride (PVDF) membrane (No. IPVH00010, Millipore, Billerica, MA, USA), electrophoretic apparatus (no. HV164-5056, Bio-Rad Hercules, CA, USA) and gel imaging system (no. GelDoc2000, Bio-Rad). Osteoclasts were harvested, lysed in ice-cold cell lysis solution (Western lysis buffer, no. P0013, Beyotime Biotech, Jiangsu, China) and centrifuged at $11,279 \mathrm{x} \mathrm{g}$. The proteins encoded by the five genes were quantified by the bicinchonic acid assay method, resolved by 8-12\% sodium dodecyl sulphate-polyacrylamide gel electrophoreses and transferred onto PVDF membranes. Following this, antibodies were added and incubated with the proteins, which were then washed with TBST and analyzed for the detection of the proteins. The primary antibodies used were: Anti-TRAP(N-17,no. sc-30832)-OSCAR (M-17, no. sc-34237) -CAII (G-2, no. sc-48351), FAS (5F9, no. sc-52394, Santa Cruz Biotechnology Inc., Santa Cruz, CA, USA) and -FASL (101624, no. ab10512 Abcam, Cambridge, UK). The antibodies were diluted to 1:2000, respectively. The membranes were placed into western eluant (no. P0023C, Beyotime Biotech) three times for $5 \mathrm{~min}$. Secondary antibodies conjugated to horseradish peroxidase were diluted to 1:5000 and washed three times for $5 \mathrm{~min}$. Protein bands were detected with an electrochemiluminesence kit (no. P0019/P0020, Beyotime Biotech).

Statistical analysis. Experiments were performed in triplicate for each sample with 3 parallel wells. Data were recorded as the mean \pm standard deviation. In this study, the data were normally distributed. Analysis of variance was used to assess statistical differences using SPSS 17.0 software (SPSS, Inc., Chicago, IL, USA). P $<0.05$ was considered to indicate a statistically significant difference.

\section{Results}

Observation of RAW264.7 cells in culture. When the RAW264.7 cells were seeded, the cells with 1-2 nuclei initially displayed a round or oval shape. Subsequent to 2 days of culture in vitro, the RAW264.7 cells grew rapidly and began to form colonies. The RAW264.7 cells occupied $80-90 \%$ of the flask surface area by the third day of culture in vitro, the number and properties of the cells were suitable for their use in osteoclast culture.

Observation of sRANKL-induced osteoclasts. Several large multinuclear cells were observed by the third day of culture when RAW264.7 cells had been treated with SRANKL. By 
Table I. Annealing temperatures and primer sequences.

\begin{tabular}{|c|c|c|c|}
\hline Primer name & Sequence $\left(5^{\prime}-3^{\prime}\right)$ & Annealing temperature $\left({ }^{\circ} \mathrm{C}\right)$ & Amplified length (bp) \\
\hline \multirow[t]{2}{*}{ Actin } & F-CTAAGGCCAACCGTGAAA & & \\
\hline & R-TGGAAGGTGGACAGTGAG & 60 & 724 \\
\hline \multirow[t]{2}{*}{ TRAP } & F-CTCCCACCCTGAGATTTG & & \\
\hline & R-GTTTCCAGCCAGCACATA & 57 & 263 \\
\hline \multirow[t]{2}{*}{ CAII } & F-GATTGGACCTGCCTCACA & & \\
\hline & R-ACACCTGGGTCTTGCTTT & 54 & 507 \\
\hline \multirow[t]{2}{*}{ OSCAR } & F-TGATTGGCACAGCAGGAG & & \\
\hline & R-AAGGCACAGGAAGGAAATAGAG & 55 & 272 \\
\hline \multirow[t]{2}{*}{ FAS } & F-AGGAGGGCAAGATAGATG & & \\
\hline & R-CTGCGACATTCGGCTTTT & 56 & 151 \\
\hline \multirow[t]{2}{*}{ FASL } & F-TGGAGCAGTCAGCGTCAG & & \\
\hline & R-ACAGGTGGTGGTGGAGGTG & 56 & 245 \\
\hline
\end{tabular}

TRAP, tartrate-reistant acid phosphatase; CAII, carbonic anhydrase II; OSCAR, osteoclast-associated receptor.

Table II. Relative RNA expression of TRAP, CAII, OSCAR and FAS/FASL genes in osteoclasts at various concentrations and administration times of ALN.

\begin{tabular}{|c|c|c|c|c|c|c|}
\hline \multirow[b]{2}{*}{ Gene } & \multirow[b]{2}{*}{ Time (h) } & \multicolumn{4}{|c|}{ Expression } & \\
\hline & & Control & $\begin{array}{c}\text { Low } \\
\text { concentration }\end{array}$ & $\begin{array}{c}\text { Medium } \\
\text { concentration }\end{array}$ & $\begin{array}{c}\text { High } \\
\text { concentration }\end{array}$ & \\
\hline \multirow[t]{4}{*}{ TRAP } & 2 & $7.510 \pm 0.02$ & $7.413 \pm 0.03$ & $7.313 \pm 0.03$ & $7.273 \pm 0.07$ & $*$ \\
\hline & 4 & $7.490 \pm 0.03$ & $6.780 \pm 0.02$ & $6.693 \pm 0.02$ & $6.557 \pm 0.06$ & $*$ \\
\hline & 6 & $7.477 \pm 0.02$ & $6.660 \pm 0.06$ & $6.587 \pm 0.15$ & $6.420 \pm 0.04$ & $*$ \\
\hline & 8 & $\begin{array}{c}7.453 \pm 0.05 \\
* *\end{array}$ & $\begin{array}{c}6.657 \pm 0.06 \\
*\end{array}$ & $\begin{array}{c}6.523 \pm 0.05 \\
*\end{array}$ & $\begin{array}{c}6.390 \pm 0.10 \\
*\end{array}$ & * \\
\hline \multirow[t]{4}{*}{ CAII } & 2 & $7.557 \pm 0.04$ & $7.350 \pm 0.04$ & $7.213 \pm 0.03$ & $7.133 \pm 0.04$ & $*$ \\
\hline & 4 & $7.487 \pm 0.12$ & $6.907 \pm 0.03$ & $6.813 \pm 0.03$ & $6.760 \pm 0.06$ & $*$ \\
\hline & 6 & $7.460 \pm 0.14$ & $6.777 \pm 0.04$ & $6.613 \pm 0.10$ & $6.590 \pm 0.02$ & * \\
\hline & 8 & $\begin{array}{c}7.430 \pm 0.13 \\
* *\end{array}$ & $\begin{array}{c}6.637 \pm 0.05 \\
*\end{array}$ & $\begin{array}{c}6.503 \pm 0.03 \\
*\end{array}$ & $\begin{array}{c}6.357 \pm 0.05 \\
*\end{array}$ & $*$ \\
\hline \multirow[t]{4}{*}{ OSCAR } & 2 & $7.420 \pm 0.05$ & $7.347 \pm 0.03$ & $7.290 \pm 0.03$ & $7.257 \pm 0.04$ & $*$ \\
\hline & 4 & $7.340 \pm 0.05$ & $7.273 \pm 0.03$ & $7.140 \pm 0.07$ & $6.877 \pm 0.12$ & $*$ \\
\hline & 6 & $7.313 \pm 0.42$ & $7.027 \pm 0.03$ & $6.843 \pm 0.08$ & $6.760 \pm 0.04$ & $*$ \\
\hline & 8 & $\begin{array}{c}6.900 \pm 0.07 \\
* *\end{array}$ & $\begin{array}{c}6.613 \pm 0.11 \\
*\end{array}$ & $\begin{array}{c}6.520 \pm 0.06 \\
*\end{array}$ & $\begin{array}{c}6.447 \pm 0.04 \\
*\end{array}$ & $*$ \\
\hline \multirow[t]{4}{*}{ FAS } & 2 & $7.533 \pm 0.06$ & $7.347 \pm 0.05$ & $7.270 \pm 0.04$ & $7.223 \pm 0.10$ & $*$ \\
\hline & 4 & $7.523 \pm 0.05$ & $7.277 \pm 0.04$ & $7.183 \pm 0.01$ & $7.083 \pm 0.04$ & $*$ \\
\hline & 6 & $7.490 \pm 0.02$ & $7.100 \pm 0.05$ & $6.747 \pm 0.06$ & $6.183 \pm 0.07$ & $*$ \\
\hline & 8 & $\begin{array}{c}7.443 \pm 0.03 \\
* *\end{array}$ & $\begin{array}{c}6.190 \pm 0.02 \\
*\end{array}$ & $\begin{array}{c}6.130 \pm 0.02 \\
*\end{array}$ & $\begin{array}{c}6.000 \pm 0.10 \\
*\end{array}$ & $*$ \\
\hline \multirow[t]{4}{*}{ FASL } & 2 & $7.713 \pm 0.12$ & $7.583 \pm 0.02$ & $7.523 \pm 0.09$ & $7.423 \pm 0.07$ & $*$ \\
\hline & 4 & $7.693 \pm 0.12$ & $6.300 \pm 0.03$ & $6.173 \pm 0.03$ & $6.153 \pm 0.02$ & $*$ \\
\hline & 6 & $7.667 \pm 0.13$ & $6.280 \pm 0.03$ & $6.167 \pm 0.03$ & $6.040 \pm 0.03$ & $*$ \\
\hline & 8 & $\begin{array}{c}7.647 \pm 0.16 \\
* *\end{array}$ & $\begin{array}{c}6.067 \pm 0.07 \\
*\end{array}$ & $\begin{array}{c}5.860 \pm 0.06 \\
*\end{array}$ & $\begin{array}{c}5.717 \pm 0.09 \\
*\end{array}$ & $*$ \\
\hline
\end{tabular}

Data are presented as the mean \pm standard deviation. $\alpha=0.05 ;{ }^{*} \mathrm{P}<0.05$ and ${ }^{* *} \mathrm{P}>0.05$. TRAP, tartrate-resistant acid phosphatase; CAII, carbonic anhydrase II; OSCAR, osteoclast-associated receptor. 
Table III. Protein expression of TRAP, CAII, OSCAR and FAS/FASL genes in osteoclasts at various concentrations and administration times of ALN.

\begin{tabular}{|c|c|c|c|c|c|c|}
\hline \multirow[b]{2}{*}{ Gene } & \multirow[b]{2}{*}{ Time (h) } & \multicolumn{4}{|c|}{ Expression } & \\
\hline & & $\begin{array}{c}\text { Control } \\
\text { concentration }\end{array}$ & $\begin{array}{c}\text { Low } \\
\text { concentration }\end{array}$ & $\begin{array}{c}\text { Medium } \\
\text { concentration }\end{array}$ & $\begin{array}{c}\text { High } \\
\text { concentration }\end{array}$ & \\
\hline \multirow[t]{5}{*}{ TRAP } & 2 & $55.167 \pm 2.07$ & $47.433 \pm 1.10$ & $34.337 \pm 0.37$ & $32.633 \pm 0.87$ & $*$ \\
\hline & 4 & $54.733 \pm 2.46$ & $43.250 \pm 0.80$ & $31.660 \pm 0.94$ & $31.367 \pm 1.10$ & $*$ \\
\hline & 6 & $53.967 \pm 3.10$ & $41.193 \pm 0.88$ & $30.727 \pm 0.80$ & $29.067 \pm 0.41$ & $*$ \\
\hline & 8 & $53.600 \pm 3.29$ & $40.440 \pm 1.06$ & $28.943 \pm 0.65$ & $28.543 \pm 0.89$ & $*$ \\
\hline & & $* *$ & $*$ & $*$ & $*$ & \\
\hline \multirow[t]{5}{*}{ CAII } & 2 & $265.333 \pm 5.50$ & $235.600 \pm 8.66$ & $220.040 \pm 0.80$ & $183.467 \pm 3.53$ & $*$ \\
\hline & 4 & $263.333 \pm 5.19$ & $230.177 \pm 5.89$ & $185.173 \pm 4.94$ & $150.567 \pm 0.70$ & $*$ \\
\hline & 6 & $262.567 \pm 5.38$ & $229.133 \pm 5.77$ & $166.143 \pm 3.51$ & $133.833 \pm 1.30$ & $*$ \\
\hline & 8 & $261.167 \pm 6.63$ & $186.607 \pm 5.30$ & $142.633 \pm 2.95$ & $124.867 \pm 4.82$ & $*$ \\
\hline & & $* *$ & $*$ & $*$ & $*$ & \\
\hline \multirow[t]{4}{*}{ OSCAR } & 2 & $5.863 \pm 0.04$ & $5.567 \pm 0.06$ & $5.210 \pm 0.04$ & $4.853 \pm 0.10$ & $*$ \\
\hline & 4 & $5.840 \pm 0.04$ & $5.250 \pm 0.05$ & $4.870 \pm 0.08$ & $4.177 \pm 0.04$ & $*$ \\
\hline & 6 & $5.810 \pm 0.05$ & $5.170 \pm 0.04$ & $4.867 \pm 0.06$ & $3.583 \pm 0.34$ & $*$ \\
\hline & 8 & $\begin{array}{c}5.757 \pm 0.05 \\
* *\end{array}$ & $\begin{array}{c}4.753 \pm 0.14 \\
*\end{array}$ & $\begin{array}{c}4.637 \pm 0.04 \\
*\end{array}$ & $\begin{array}{c}3.937 \pm 0.08 \\
*\end{array}$ & $*$ \\
\hline \multirow[t]{5}{*}{ FAS } & 2 & $6.657 \pm 0.08$ & $6.267 \pm 0.04$ & $6.077 \pm 0.04$ & $5.433 \pm 0.05$ & $*$ \\
\hline & 4 & $6.620 \pm 0.11$ & $6.203 \pm 0.06$ & $5.903 \pm 0.04$ & $4.600 \pm 0.05$ & $*$ \\
\hline & 6 & $6.600 \pm 0.10$ & $5.950 \pm 0.17$ & $5.430 \pm 0.22$ & $4.193 \pm 0.04$ & $*$ \\
\hline & 8 & $6.487 \pm 0.17$ & $5.840 \pm 0.31$ & $5.233 \pm 0.09$ & $3.570 \pm 0.03$ & $*$ \\
\hline & & $* *$ & $*$ & $*$ & $*$ & \\
\hline \multirow[t]{4}{*}{ FASL } & 2 & $6.900 \pm 0.04$ & $6.730 \pm 0.04$ & $6.493 \pm 0.08$ & $5.107 \pm 0.10$ & $*$ \\
\hline & 4 & $6.863 \pm 0.04$ & $6.333 \pm 0.10$ & $5.370 \pm 0.09$ & $4.750 \pm 0.09$ & $*$ \\
\hline & 6 & $6.837 \pm 0.05$ & $6.090 \pm 0.05$ & $4.827 \pm 0.06$ & $4.663 \pm 0.04$ & $*$ \\
\hline & 8 & $\begin{array}{c}6.797 \pm 0.04 \\
* *\end{array}$ & $\begin{array}{c}5.823 \pm 0.34 \\
*\end{array}$ & $\begin{array}{c}4.807 \pm 0.19 \\
*\end{array}$ & $\begin{array}{c}4.383 \pm 0.10 \\
*\end{array}$ & $*$ \\
\hline
\end{tabular}

Data are presented as the mean \pm standard deviation; $\alpha=0.05 ;{ }^{*} \mathrm{P}<0.05$ and ${ }^{* *} \mathrm{P}>0.05$. TRAP, tartrate-resistant acid phosphatase; CAII, carbonic anhydrase II; OSCAR, osteoclast-associated receptor.

the fifth day, increased numbers of multinuclear cells were observed and by the sixth day there were large numbers of the cells present. The cells were large and irregular in shape, and several nuclei were observed (Fig. 1).

TRAP staining of osteoclasts. The multinuclear cells were confirmed to be osteoclasts by TRAP staining features, where the cytoplasm was a rose-pink color and the nuclei appeared light yellow (Fig. 2). The nucleoli were also clearly observed.

mRNA expression of TRAP, CAII, OSCAR and FAS/FASL in osteoclasts. The mRNA expression of TRAP, CAII, OSCAR and FAS/FASL significantly decreased when osteoclasts had been exposed to ALN in a dose-dependent manner for the indicated incubation times. In addition, the mRNA expression of TRAP, CAII, OSCAR and FAS/FASL significantly decreased when osteoclasts had been exposed to ALN in a time-dependent manner for the indicated dose concentrations (Table II and Figs. 3 and 5; $\mathrm{P}<0.05$ ). No significant differ- ence in expression was identified between the control groups $(\mathrm{P}>0.05)$.

Protein expression of TRAP, CAII, OSCAR and FAS/FASL in osteoclasts. The protein expression of TRAP, CAII, OSCAR and FAS/FASL significantly decreased when osteoclasts were exposed to ALN in a dose-dependent manner for the indicated incubation times. Furthermore, the protein expression of TRAP, CAII, OSCAR and FAS/FASL also significantly decreased when osteoclasts were exposed to ALN in a time-dependent manner for the indicated dose concentrations (Table III; Figs. 4 and 6; $\mathrm{P}<0.05$ ). No significant difference in expression was observed between the control groups $(\mathrm{P}>0.05)$.

\section{Discussion}

The inhibitory mechanism of ALN occurs in a number of stages. Initially, ALN is selectively enriched in the bone tissue due to an infusion of ALN into the cytoplasm, which 


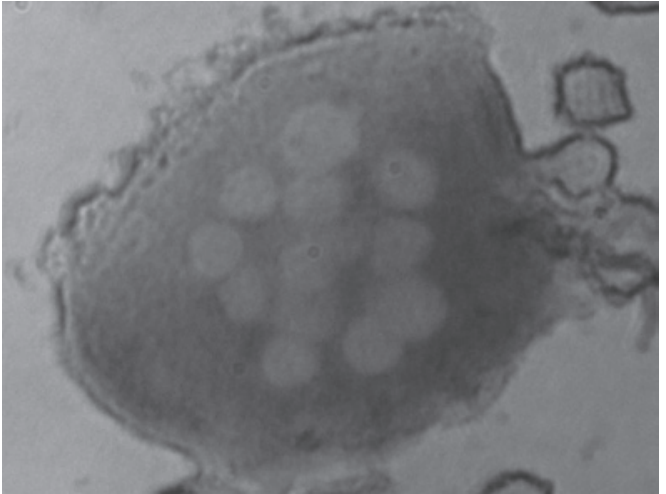

Figure 1. A representative osteoclast containing several nuclei (magnification, $\mathrm{x} 400$; no staining). The osteoclast has an irregular shape and several processes from the cytomembrane.

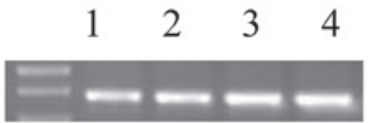

Actin

$2 \mathrm{~h}$

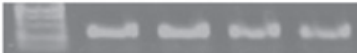

$4 \mathrm{~h}$

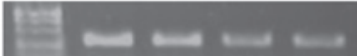

$6 \mathrm{~h}$

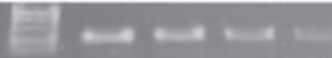

$8 \mathrm{~h}$

$2 \mathrm{~h}$

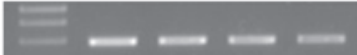

$4 \mathrm{~h} \ldots \ldots$

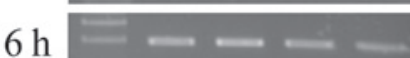

CAII

$8 \mathrm{~h}$

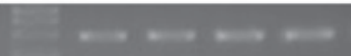

TRAP

$2 \mathrm{~h}$

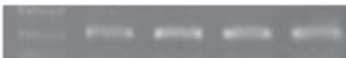

$4 \mathrm{~h}+\ldots+\cdots$

$6 \mathrm{~h}$

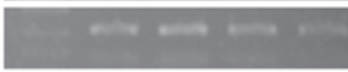

OSCAR

$8 \mathrm{~h}$

$2 \mathrm{~h}$

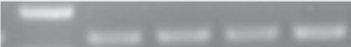

$4 \mathrm{~h}$

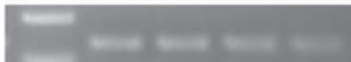

$6 \mathrm{~h}$

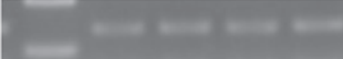

\section{FAS}

$8 \mathrm{~h}$

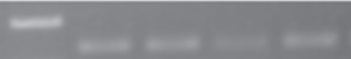

$2 \mathrm{~h}$

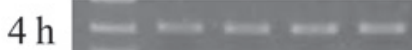

$6 \mathrm{~h}$

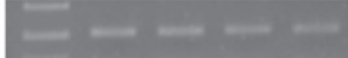

$8 \mathrm{~h}$

\section{FASL}

Figure 3. qPCR analysis showing mRNA expression of tartrate-resistant acid phosphatase (TRAP), carbonic anhydrase II (CAII), osteoclast-associated receptor (OSCAR), and FAS/FASL genes in osteoclasts. Lanes 1, 2, 3 and 4 are the control, and low, medium and high concentration groups, respectively. Cells were incubated for 2, 4, 6 and $8 \mathrm{~h}$ with alendronate. $\beta$-actin was used as an internal control.

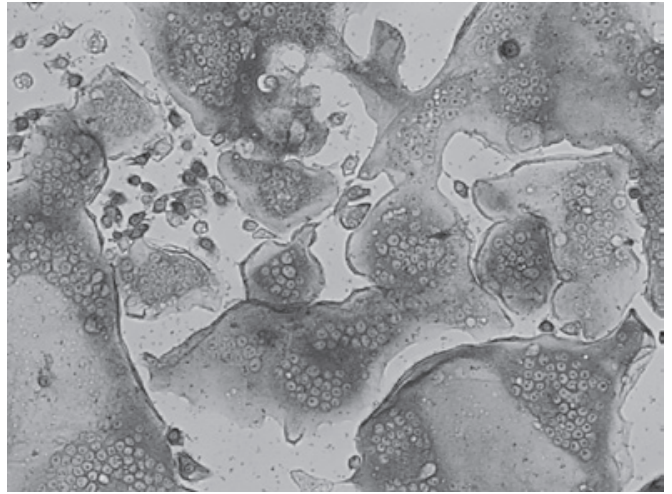

Figure 2. Tartrate-resistant acid phosphatase staining of osteoclasts (magnification, $\mathrm{x} 400)$. The nuclei exhibit vacuolar shape in the cytoplasm.

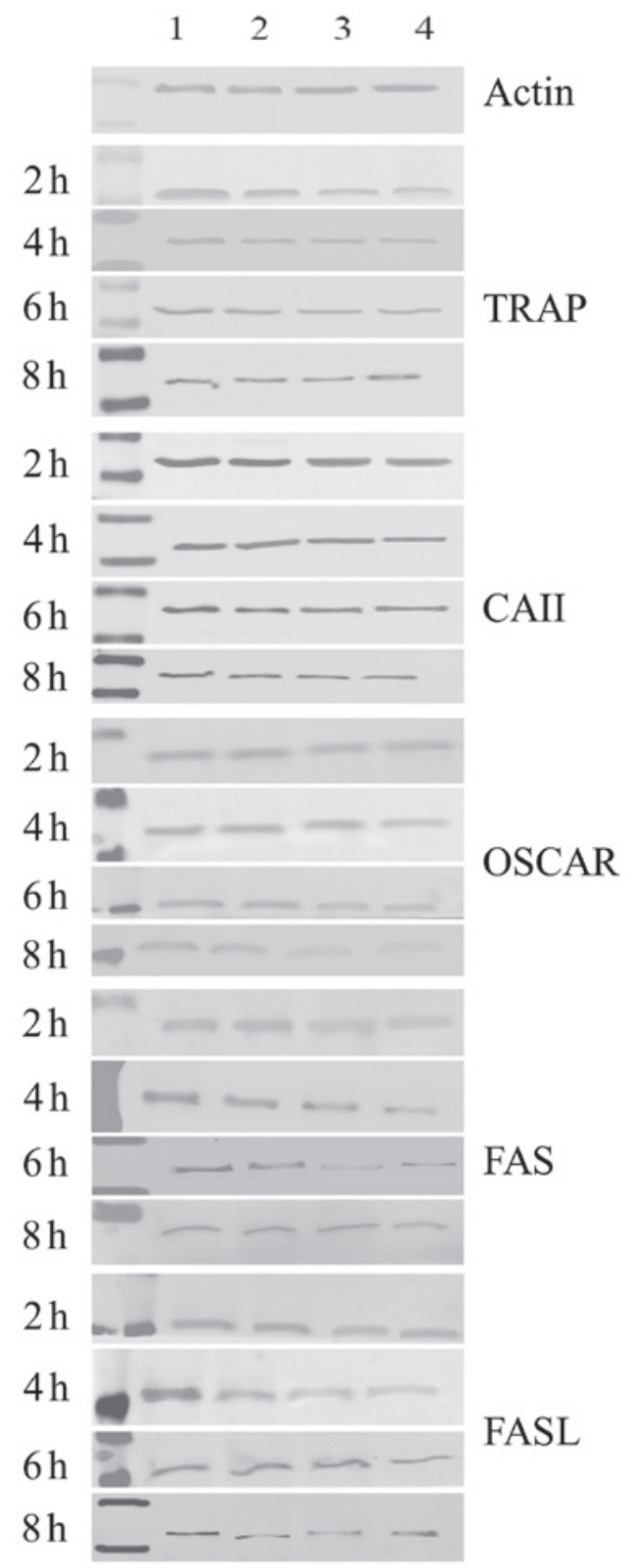

Figure 4. Western blot analysis of tartrate-resistant acid phosphatase (TRAP), carbonic anhydrase II (CAII), osteoclast-associated receptor (OSCAR) and FAS/FASL protein expression in osteoclasts. Lanes 1, 2, 3 and 4 are the control, and low, medium and high concentration groups, respectively. Cells were incubated for 2, 4, 6 and $8 \mathrm{~h}$ with alendronate. $\beta$-actin was used as an internal control. 
A

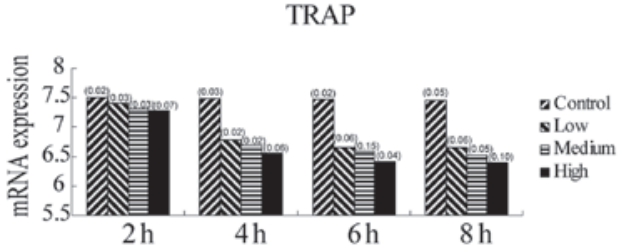

C

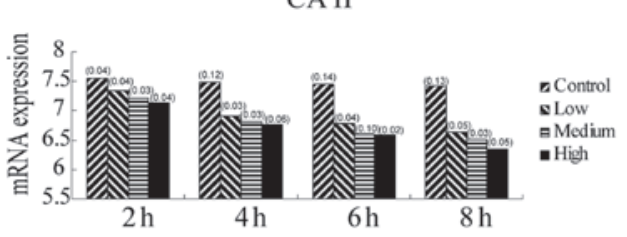

$\mathbf{E}$

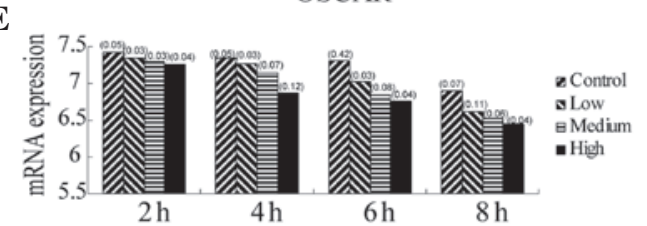

FAS

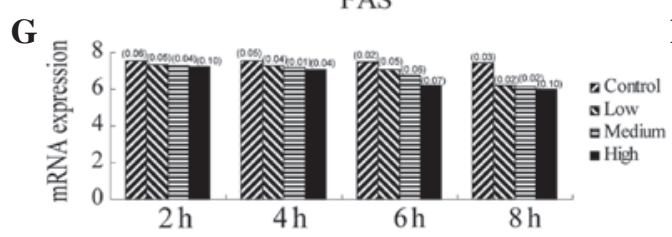

I

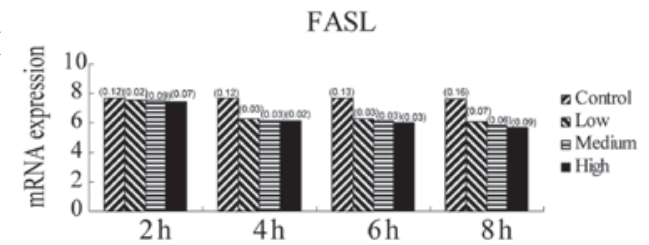

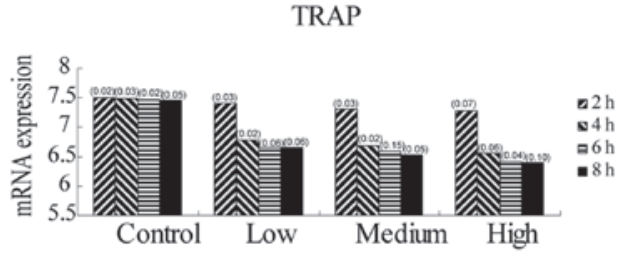

D

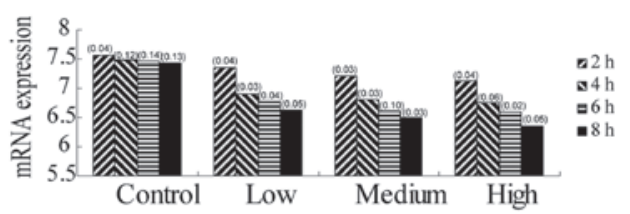

$\mathbf{F}$

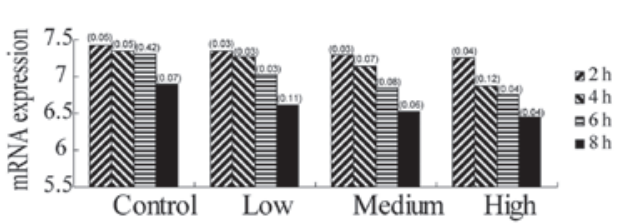

FAS

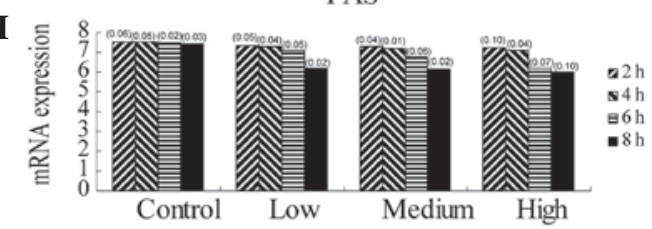

$\mathbf{J}$

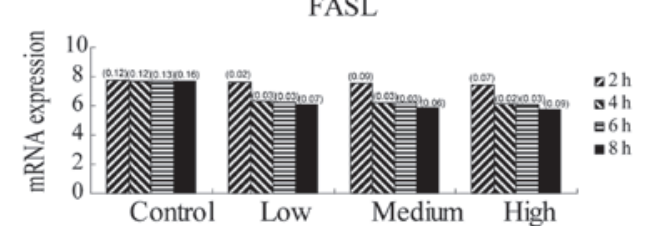

Figure 5. Histogram of tartrate-resistant acid phosphatase (TRAP), carbonic anhydrase II (CAII), osteoclast-associated receptor (OSCAR) and FAS/FASL mRNA expression in osteoclasts treated with ALN. (A, C, E, G and I) mRNA expression of the genes in the presence of alendronate (ALN) for the indicated incubation times. (B, D, F, H and J) mRNA expression of the genes in the presence of ALN at the indicated concentrations.

interferes with osteoclast differentiation, maturation and recruitment. Osteoclasts then undergo apoptosis during which the ALN-mediated inhibition is most prominent. However, it has also been demonstrated that ALN may be metabolized as a quasi-ATP decoy, thereby affecting ATPase in osteoclasts. In addition, ALN has been shown to inhibit the mevalonic acid pathway during cholesterol metabolism and subsequently inactivate the prenylation of osteoclasts by affecting GTP-binding proteins (19). Previously, several studies have demonstrated that ALN may inhibit osteoclast function. The addition of various concentrations of ALN to calcium phosphate bone cement was shown to inhibit osteoclastogenesis and osteoclast function (18). Another study indicated that bisphosphonate exhibited an inhibitory effect on osteoclast proliferation (15). Kawata et al (16) suggested that ALN inhibited the resorption of ectopic bone grafts when injected at specific concentrations. Another study demonstrated that ALN affected the mineral density and remodeling of bone tissue (20). In addition,
RANKL-induced osteoclast differentiation of RAW264.7 cells was inhibited on ALN-coated titanium surfaces and the mRNA expression of TRAP was downregulated (17). Therefore, based on these results, additional studies were required to investigate the mechanism of the ALN-mediated inhibition of osteoclasts.

The ALN concentration and duration of incubation are critical parameters when assessing the effects of this bisphosphonate on osteoclasts. ALN, similar to numerous other inhibitors, is administrated based on a strict dose and time schedule. The results of this study suggested that ALN affected osteoclasts in a dose-dependent manner and it has been shown that high doses of ALN exhibited deleterious effects on osteoclastic function (21). Koshihara et al (22) demonstrated that treatment of osteoclasts with $10^{-4} \mathrm{M}$ ALN for $6 \mathrm{~h}$ resulted in a breakdown of the actin ring and that cell mobility was decreased compared with that of cells treated with $10^{-5} \mathrm{M}$ ALN. In addition, only a partial recovery from contraction was observed when the cells were treated with $10^{-4} \mathrm{M}$ ALN compared with 

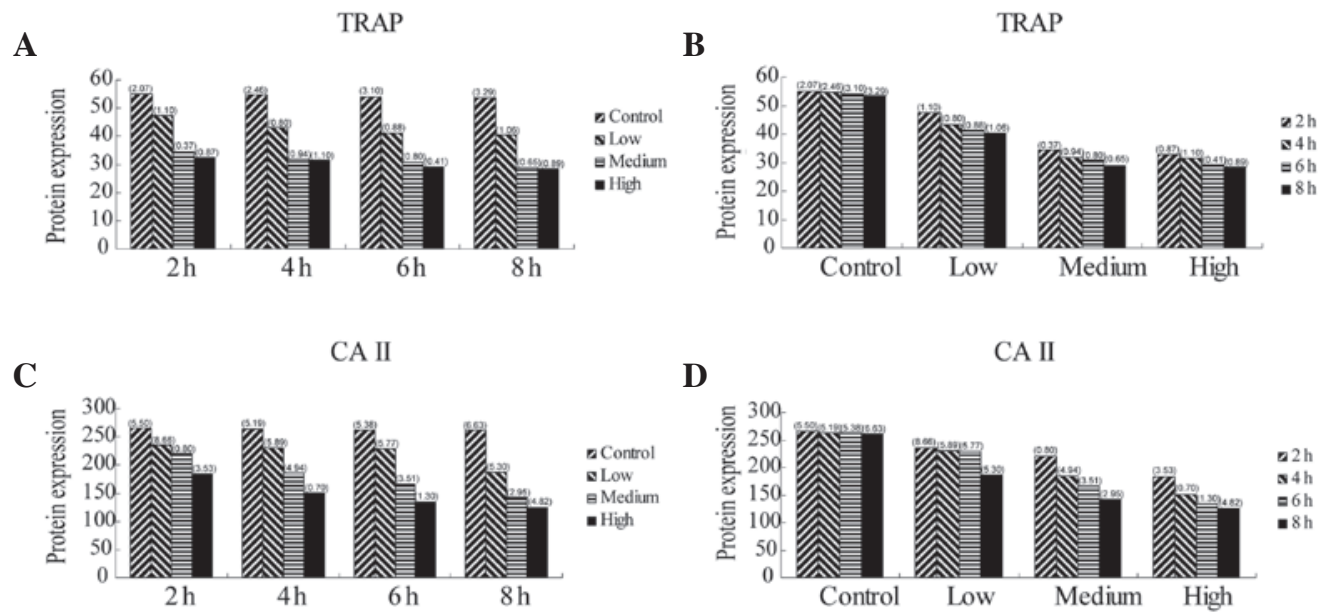

OSCAR

E

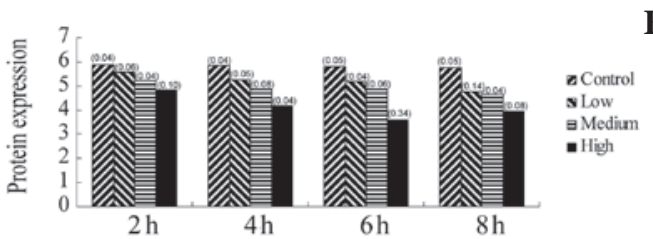

FAS

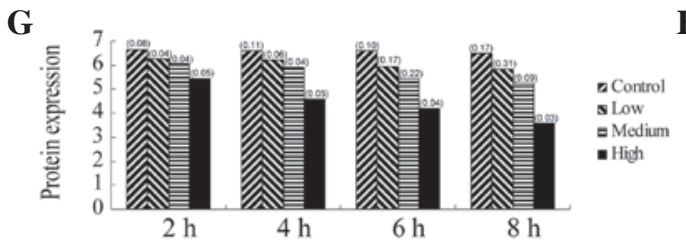

FASL

I

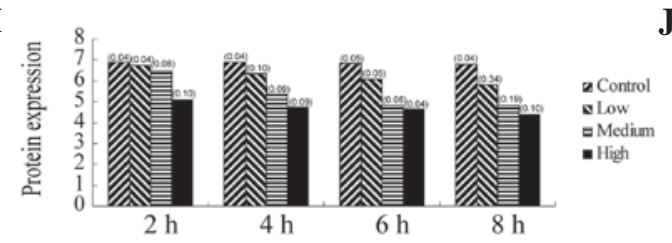

F

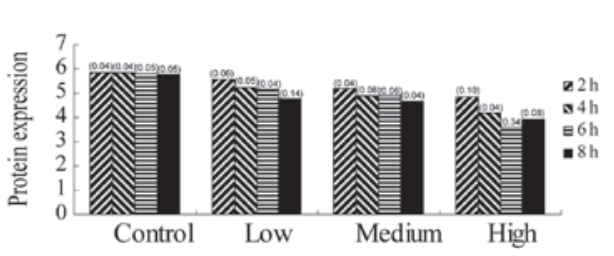

FAS

H

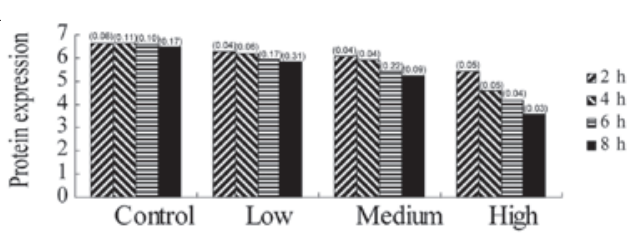

FASL

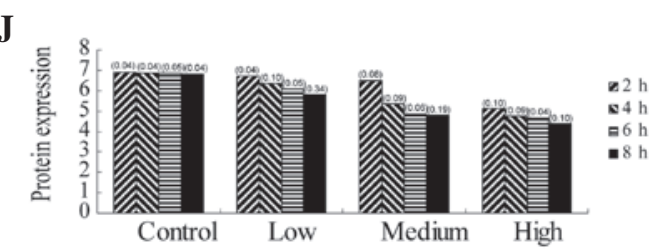

Figure 6. Histogram of tartrate-resistant acid phosphatase (TRAP), carbonic anhydrase II (CAII), osteoclast-associated receptor (OSCAR) and FAS/FASL protein expression in osteoclasts treated with ALN. (A, C, E, G and I) Protein expression of the genes in the presence of alendronate (ALN) for the indicated incubation times. (B, D, F, H and J) Protein expression of the genes in the presence of ALN at the indicated concentrations.

that of the other dose groups. However, the removal of ALN treatment completely restored the function and appearance of the cells. Therefore, the effects of ALN on osteoclast motility and morphology were reversible at a concentration of $10^{-5} \mathrm{M}$, suggesting that ALN did not lead to permanent cell damage in osteoclasts at this dose, and therefore it was an appropriate and effective dose for bone resorption (22). In another study, ALN inhibited bone resorption at concentrations $\leq 10^{-7} \mathrm{M}$. At the highest concentration of $10^{-5} \mathrm{M}$, the osteoclast number and resorption were markedly reduced (23).

In our previous study, it was demonstrated that osteoclasts possessed a time rhythm, which was not optimal for the detection of molecular changes when the cells were cultured for $<24 \mathrm{~h}$. The mRNA expression, osteoclastic apoptosis and other changes were only observed when the cells were cultured for $>48 \mathrm{~h}$ (24). Based on these results, we previously concluded that osteoclast mRNA expression reached a peak level following $24 \mathrm{~h}$ of culture and exhibited higher sensitivity to the surrounding stimuli at that time point (24). The results from the present study demonstrated that osteoclasts reached peak mRNA expression subsequent to 6 days of culture. In addition, the effects of ALN on the mRNA and protein expression of TRAP, CAII, OSCAR and FAS/FASL at specific concentrations $\left(10^{-5} \mathrm{M}, 10^{-6} \mathrm{M}\right.$ and $\left.10^{-7} \mathrm{M}\right)$ and duration of incubation $(0,2,4,6$ and $8 \mathrm{~h})$ were determined. It was demonstrated that that the expression of these genes decreased marginally over the indicated incubation time; however, the differences between time points were not significant. Therefore, osteoclast apoptosis did not occur following $8 \mathrm{~h}$ of treatment with ALN.

The mechanism of action of ALN on osteoclasts has been the focus of previous studies. D'Amelio et al (25) suggested 
that ALN predominantly acted on mature bone resorbing osteoclasts during short-term treatment, but decreased osteoclast precursors and serum RANKL levels after longterm treatment. Fisher et al (26) also concluded that ALN acted directly on osteoclasts and inhibited a rate-limiting step in the cholesterol biosynthesis pathway, which was essential for osteoclast function. In addition, other studies have determined that ALN bound to resorption surfaces and was released locally during acidification. In addition, an increasing concentration of ALN prevented osteoclastic resorption and membrane ruffling (27). However, Owens et al (28) hypothesized that the inhibitory mechanism of ALN was not due to resorption.

Findings of another study showed that the reduced efficacy of ALN to prevent bone erosion may be due to locally increased levels of tumor necrosis factor (TNF), which resulted in the upregulation of ETS-2 expression in osteoclasts. Moreover, BCL-XL expression was stimulated, which reduced cell susceptibility to ALN-induced apoptosis (29). Wang et al (30) also demonstrated that ALN promoted the apoptosis of osteoclasts, which was related to expression of the FAS gene. However, another hypothesized mechanism suggested that ALN suppression of bone resorption was independent of its effect on apoptosis (31). In addition, ALN impaired intracellular vesicle transport in osteoclasts, which suggested that the effects on apoptosis may be a secondary mechanism (32).

Kum et al (33) hypothesized that the ALN inhibitory mechanism was not related to the inhibition of IL- 6 production. Colucci et al (34) indicated that the inhibitory effect of ALN was due to the interference with receptors and bone matrix proteins, such as $\alpha 5 \beta 3$ integrins. Furthermore, ALN induced $\mathrm{Ca}^{2+}$-mediated intracellular signaling in osteoclasts and triggered a 2-fold increase in the intracellular calcium concentration. Moreover, the study by Schmidt et al (35) suggested that a tyrosine phosphatase may also be a putative molecular target of ALN.

The results of this study have shown that ALN inhibited osteoclasts partly by decreasing the mRNA and protein expression of important cell molecules, including TRAP, CAII, OSCAR and FAS/FASL. The expression of these proteins decreased in an ALN concentration- and time-dependent manner. In addition, the results were concordant with previous studies. In conclusion, osteoclasts negatively responded to ALN treatment. In addition, ALN activated several signaling pathways in osteoclasts, such as $\mathrm{Ca}^{2+}$-mediated intracellular signaling, tyrosine phosphatase activity and cholesterol biosynthesis pathways and ALN induced apoptosis in osteoclasts.

\section{Acknowledgements}

This study was supported by the Department of Education Foundation of the Zhejiang Province of China (grant nos. N20080180, Y201018976, Y201329982 and N20110143), the Department of health Foundation of the Zhejiang Province of China (grant no. 2013KYB166), the Zhejiang Provincial Natural Science Foundation of China (grant nos. Y2080340 and LY12H14004) and the Zhejiang Provincial and Ministry joint Project (grant no. WKJ2011-2-009).

\section{References}

1. Doody KM, Bussières-Marmen $\mathrm{S}$, Li A, et al: $\mathrm{T}$ cell protein tyrosine phosphatase deficiency results in spontaneous synovitis and subchondral bone resorption in mice. Arthritis Rheum 64: 752-761, 2012.

2. Klijn RJ, van den Beucken JJ, Bronkhorst EM, et al: Predictive value of ridge dimensions on autologous bone graft resorption in staged maxillary sinus augmentation surgery using Cone-Beam CT. Clin Oral Implants Res 23: 409-415, 2012.

3. Nonaka CF, Cavalcante RB, Nogueira RL, et al: Immunohistochemical analysis of bone resorption regulators (RANKL and OPG), angiogenic index, and myofibroblasts in syndrome and non-syndrome odontogenic keratocysts. Arch Oral Biol 57: 230-237, 2012.

4. Hong ZQ, Tao LM and Li L: Effect of stress on mRNA expression of $\mathrm{H}^{+}$-ATPase in osteoclasts. Mol Cell Biochem 343: 183-190, 2010.

5. Nakayama T, Mizoguchi T, Uehara S, et al: Polarized osteoclasts put marks of tartrate-resistant acid phosphatase on dentin slices - a simple method for identifying polarized osteoclasts. Bone 49: 1331-1339, 2011.

6. Fujisaki K, Tanabe N, Suzuki N, et al: Receptor activator of NF-kappaB ligand induces the expression of carbonic anhydrase II, cathepsin K, and matrix metalloproteinase-9 in osteoclast precursor RAW264.7 cells. Life Sci 80: 1311-1318, 2007.

7. Zhang Q, Liang X, Zhu B, et al: Effects of fluid shear stress on mRNA expression of carbonic anhydrase II in polarized rat osteoclasts. Cell Biol Int 30: 714-720, 2006.

8. Goettsch C, Rauner M, Sinningen K, et al: The osteoclast-associated receptor (OSCAR) is a novel receptor regulated by oxidized low-density lipoprotein in human endothelial cells. Endocrinology 152: 4915-4926, 2011.

9. Ishikawa S, Arase N, Suenaga T, et al: Involvement of FcRgamma in signal transduction of osteoclast-associated receptor (OSCAR). Int Immunol 16: 1019-1025, 2004.

10. Kim JH, Kim K, Jin HM, et al: Upstream stimulatory factors regulate OSCAR gene expression in RANKL-mediated osteoclast differentiation. J Mol Biol 383: 502-511, 2008.

11. Kim JH, Kim K, Youn BU, et al: MHC class II transactivator negatively regulates RANKL-mediated osteoclast differentiation by downregulating NFATc1 and OSCAR. Cell Signal 22: 1341-1349, 2010.

12. Kovacić N, Lukić IK, Grcević D, et al: The Fas/Fas ligand system inhibits differentiation of murine osteoblasts but has a limited role in osteoblast and osteoclast apoptosis. J Immunol 178: 3379-3389, 2007.

13. Krum SA, Miranda-Carboni GA, Hauschka PV, et al: Estrogen protects bone by inducing Fas ligand in osteoblasts to regulate osteoclast survival. EMBO J 27: 535-545, 2008.

14. Nakamura T, Imai Y, Matsumoto T, et al: Estrogen prevents bone loss via estrogen receptor alpha and induction of Fas ligand in osteoclasts. Cell 130: 811-823, 2007.

15. Boanini E, Torricelli P, Gazzano M, et al: Alendronate-hydroxyapatite nanocomposites and their interaction with osteoclasts and osteoblast-like cells. Biomaterials 29: 790-796, 2008.

16. Kawata T, Tenjou K, Tokimasa C, et al: Effect of alendronate on osteoclast differentiation and bone volume in transplanted bone. Exp Anim 53: 47-51, 2004.

17. Moon HJ, Yun YP, Han CW, et al: Effect of heparin and alendronate coating on titanium surfaces on inhibition of osteoclast and enhancement of osteoblast function. Biochem Biophys Res Commun 413: 194-200, 2011.

18. Panzavolta S, Torricelli P, Bracci B, et al: Alendronate and Pamidronate calcium phosphate bone cements: setting properties and in vitro response of osteoblast and osteoclast cells. J Inorg Biochem 103: 101-106, 2009.

19. Rogers MJ, Frith JC, Luckman SP, et al: Molecular mechanisms of action of bisphosphonates. Bone 24: 73S-79S, 1999.

20. Sugata Y, Sotome S, Yuasa M, et al: Effects of the systemic administration of alendronate on bone formation in a porous hydroxyapatite/collagen composite and resorption by osteoclasts in a bone defect model in rabbits. J Bone Joint Surg Br 93: 510-516, 2011.

21. Sama AA, Khan SN, Myers ER, et al: High-dose alendronate uncouples osteoclast and osteoblast function: a study in a rat spine pseudarthrosis model. Clin Orthop Relat Res 425: 135-142, 2004. 
22. Koshihara Y, Kodama S, Ishibashi H, et al: Reversibility of alendronate-induced contraction in human osteoclast-like cells formed from bone marrow cells in culture. J Bone Miner Metab 17: 98-107, 1999.

23. Breuil V, Cosman F, Stein L, et al: Human osteoclast formation and activity in vitro: effects of alendronate. J Bone Miner Res 13 1721-1729, 1998

24. Hong ZQ, Tao LM and Li L: mRNA expression in osteoclasts: a chronobiological approach. Biological Rhythm Research 42 : 287-298, 2011.

25. D'Amelio P, Grimaldi A, Cristofaro MA, et al: Alendronate reduces osteoclast precursors in osteoporosis. Osteoporos Int 21: 1741-1750, 2010

26. Fisher JE, Rogers MJ, Halasy JM, et al: Alendronate mechanism of action: geranylgeraniol, an intermediate in the mevalonate pathway, prevents inhibition of osteoclast formation, bone resorption, and kinase activation in vitro. Proc Natl Acad Sci USA 96: 133-138, 1999.

27. Sato M, Grasser W, Endo N, et al: Bisphosphonate action. Alendronate localization in rat bone and effects on osteoclast ultrastructure. J Clin Invest 88: 2095-2105, 1991.

28. Owens JM, Fuller K and Chambers TJ: Osteoclast activation: potent inhibition by the bisphosphonate alendronate through a nonresorptive mechanism. J Cell Physiol 172: 79-86, 1997.
29. Zhang Q, Badell IR, Schwarz EM, et al: Tumor necrosis factor prevents alendronate-induced osteoclast apoptosis in vivo by stimulating $\mathrm{Bcl}-\mathrm{xL}$ expression through Ets-2. Arthritis Rheum 52: 2708-2718, 2005.

30. Wang XM, Yu SF and Yang ZP: Apoptosis of osteoclast-like cells induced by alendronate is related to Fas gene expression. Chin J Dent Res 3: 26-32, 2000.

31. Halasy-Nagy JM, Rodan GA and Reszka AA: Inhibition of bone resorption by alendronate and risedronate does not require osteoclast apoptosis. Bone 29: 553-559, 2001.

32. Alakangas A, Selander K, Mulari M, et al: Alendronate disturbs vesicular trafficking in osteoclasts. Calcif Tissue Int 70: 40-47, 2002.

33. Kum KY, Park JH, Yoo YJ, et al: The inhibitory effect of alendronate and taurine on osteoclast differentiation mediated by Porphyromonas gingivalis sonicates in vitro. J Endod 29: 28-30, 2003.

34. Colucci S, Minielli V, Zambonin G, et al: Alendronate reduces adhesion of human osteoclast-like cells to bone and bone protein-coated surfaces. Calcif Tissue Int 63: 230-235, 1998.

35. Schmidt A, Rutledge SJ, Endo N, et al: Protein-tyrosine phosphatase activity regulates osteoclast formation and function: inhibition by alendronate. Proc Natl Acad Sci USA 93: 3068-3073, 1996. 